\title{
Develop a fashion based sustainable business strategy to protect the latest threat of minimum wages in Bangladesh garments industry
}

\begin{abstract}
In the most recent year, Bangladesh's clothing industry is contributing 84 percent of yearly fare with a commitment of more than 32 billion to the absolute economy. To precede, this achievement the lowest pay permitted by law and specialist distress is the most recent danger. Bangladesh market is ahead against some remaining contenders like India, Vietnam, Pakistan, Srilanka because of the low work cost of our nation. Then again, the lowest pay permitted by law is an appealing approach apparatus for neediness decrease and social equity in the eye of the public authority. Yet, European and American purchasers are thorough to choose the all-out FOB on one computer piece of clothing for their business strategy. In the present circumstance, we need to support this serious market. In this study, the author builds up an applied exploration structure for getting away from the pursuer. As per the reasonable system, information has been gathered from various useful sources in Bangladesh. For gathering information, the creators have taken 05 composite processing plants of Bangladesh. This exploration shows various ways for feasible extravagant sort of trendy items to conquer this test. The outcomes can be actualized by the industrial facility of Bangladesh for the future turn of events.
\end{abstract}

Keywords: sustainable fashion, fast fashion \& supply chain, garments costing, fashion tools implementation, fast fashion, garments costing, living wage of garments worker
Volume 7 Issue I - 202I

\author{
Md Rajib Raihan,' Md Eanamul Haque \\ Nizam, ${ }^{2}$ Abu Bakr Siddique, ${ }^{3}$ Md \\ Moniruzzaman ${ }^{4}$ \\ 'MSc. Student, Faculty of Textile Engineering, BGMEA University \\ of Fashion \& Technology [BUFT], Bangladesh \\ ${ }^{2}$ Assistant Professor Department of Textile engineering, \\ Bangladesh University of Business \& Technology [BUBT], \\ Bangladesh \\ ${ }^{3}$ Dean \& Professor, Faculty of Textile Engineering, BGMEA \\ University of Fashion \& Technology [BUFT], Bangladesh \\ ${ }^{4}$ Lecturer, Department of Fashion Design \& Technology (FDT), \\ BGMEA University of Fashion \& Technology (BUFT), Nishatnagor, \\ Turag, Dhaka-1216, Bangladesh
}

Correspondence: Md Eanamul Haque Nizam, Assistant
Professor, Department of Textile engineering, Bangladesh
University of Business \& Technology [BUBT], Mirpur,
Dhaka-1 206, Bangladesh, Email eanamulhaqu@bubt.edu.bd

Received: February 10, 2021 | Published: February 19, 2021

\section{Introduction}

Owing to the political calm and the strong economic rebound in the Western world, prospects for the garments business are better than ever. Since Bangladesh is the second-largest garment exporting nation in the world, there are opportunities for growth here too. ${ }^{1}$ China interestingly still holds more than $38 \%$ market share and could stabilize its huge export to the US. In one year (ending by April 2016) China alone exported more than USD 42.5 billion while Bangladesh at the same period exported USD 5.6 billion. However, the good news for Bangladesh is that it is fighting well in increasing its market share in the US market. Bangladesh's export is increased by $9.68 \%$ while Vietnam's rate of market growth is $10.17 \%$. Vietnam is the fastest market growing nation and Bangladesh are following them. Bangladesh is the fourth biggest market holder following China, Vietnam, and India. ${ }^{2}$ Bangladesh's strength in formal garment production and higher economic growth in populous Asian countries have also helped such shipments to increase. The monthly minimum wage in some parts of China reached \$321 USD in 2016, which is \$253 USD higher than in Bangladesh (\$68 USD/month). ${ }^{3}$ Manufacturers are selling the garments directly to the end consumers then it's very important to estimate the cost very accurately. Praising of the garment can be done by manufacturing cost added with estimated mark-up or profit $\%$ to it. In order to do a perfect garment costing, one must know about all the activities including purchase of fabrics, sewing, packing, transport, overheads, etc., and also about their costs, procedures, advantages, and risk factors. Merchandiser must be aware that there are always fluctuations in the costs of raw materials and accessories, charges of knitting, processing, finishing, sewing, and packing, charges of transport and conveyance. The costing is done by keeping in mind the cost of the various raw materials, the operating cost of the company, the competition, and the expected profit of the organization.
At the same time, it is necessary to keep in mind the buyer's cost expectations. The components on which the cost of the garment depends is as follows Fabric, Trims, Cut Make \& Trim charges, Valueadded services: printing, embroidery, washing, applique, Testing of the garment, Quality, Transportation and logistics cost, Profit of the manufacturing organization. The parameters that affect the garment cost mostly are; Material cost, embellishment cost \& labor cost.

Labor cost per minute $=($ Monthly salary of an operators/Total minutes available in the month) at $100 \%$ efficiency $\mathrm{CM}$ cost $=(\mathrm{SAM}$ of the garment * Minute cost of the labor)/Line efficiency (\%). ${ }^{4}$

Where labor cost is has a big impact on the total FOB of the garments because minimum wage is a vital issue of Garments costing. There is a hugely competitive market of garments/clothing where an effective brand strategy plays an important role. Brand image is actually a general perception that is found in the minds of customers. It has been well defined that consumer behavior is based on the selection of the goods till the consumption which satisfies their needs and wants. In this fast-fashion world, designers are competing on their marketing strategies. Fast fashion brands have good performance due to quick action in adopting the new trends of production and marketing them as compared to other brands. Most of the well-known retailers such as Zara, Hennes \& Mauritz (H\&M), and Next originated from Europe and have the same strategy. ${ }^{5}$ Europe is home to some of the most lucrative markets for apparel and clothing worldwide. ${ }^{6}$ Among the leading European countries initially, "fast fashion" was about increasing the speed of production, reducing the time it takes to go from fashion design to the final product on shelves. Now fast fashion is less about fast production-regular drops, rather than seasonal collections have become the standard on the high street-and more about sales-how much product can be shifted, and how quickly. Fashion retailers believe that the social and environmental aspects of 
sustainability are inherently linked; one does not come without the other. Every garment has an environmental footprint at every stage in its production. When it comes to benefits to people, the case for fast fashion may have a defense. Take Bangladesh as an example a primary production hub for fast fashion retailers globally. ${ }^{7}$ Above this backgrounder study, we can understand that fashion marking is growing rapidly, and if we want to sustain this market, we have to be aware of our fashion strategy. But we are not fashion-sensitive people. And if we want to sustain in the world with the fashion market that we have to overcome all our internal threats. Our weapons have to achieve goals:

\section{a) Dedicated Government}

b) Low labor cost

\section{c) Efficient Environment}

\section{d) Efficient and effective worker}

There is a lot of lacking \& threats in the RMG sector which may destroy this whole sector within a moment like the weak physical infra-structure of a garments factory, political instability, less concern for humans. We have to solve those problems before any disaster. ${ }^{8}$

\section{The aim of this research}

In this research, the author tries to find out different angles to develop sustainable business strategies for the RMG industries of Bangladesh. This study explains Fast Fashion, which is a new concept in the Bangladesh garments industry. Also, it's a new taste to the European market. That will motivate our manufacturer \& make awareness about fast fashion the significant goal of this research. The author also develops the sustainability concept this is the latest trend all over the world. Establishment of a vision that, sustainable fashion is the solution to overcome the all difficult challenges of the Bangladesh garments industry. That will make a positive relation between Fast Fashion \& supply chain demand to full fill the quality up to customer satisfactory level. This study also established a fancybased fashion market related to costing as well as making a parallel relation among them. ${ }^{9}$

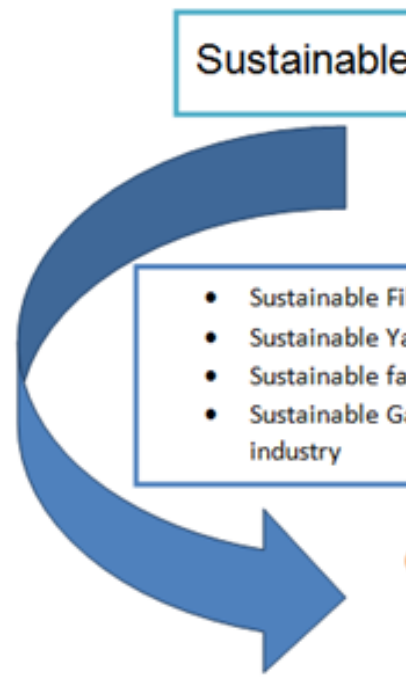

Figure I Formation of fancy product.

\section{Material and methods}

As the research is based on the minimum wage \& fashion industry that's why the author has done their survey online as well as in the garments factory of Bangladesh. Issues are minimum wage (Figures 1-3) of our worker that's why the research was exploratory online and focused on the salary of specific aspects of a major retailer's business. ${ }^{11}$ The case study approach is common in logistics and supply chain research whereby a better understanding of supply chain management challenges. Firstly in order to monitor the success of the strategy, the researchers did 'mystery shopping' check as well as online checks on the internet \& the market? Performance of the 20 key lines has to measure the living standard of our garments worker. On the other hand, uses researchers find, the act of customers or potential customers who completely related to the retail \& business. ${ }^{12}$ The primary research for this study was conducted in a series of phases and used a variety of methods. Initially, a series of face-toface interviews were held with four key informants in a mediumsized garments manufacturing company in the region to glean a better understanding of the campaign and its implementation at the store level. Secondly, we had to conduct three interviewees, the store manager, a customer assistant (floor operations), and a customer assistant (stock control) who had a total of 15 years of service with the shop. The store manager was responsible for communicating the key objectives of the campaign to the region (the availability champion) and the customer assistants were responsible for sales-flow standards and stock accuracy respectively. Finally, the second research study focused on the product categories which are very common in our garments market. Because it is required to have a constant state of availability; this product category is usually planned into the product catalogs of fashion retailers for up to six months. The research sample was designed to include middle-market retailers as research is likely to have more relevance to this section of the fashion retail sector. The reasoning behind such an argument is that mid-market fashion retailers have a more consistent product offering than their fastfashion counterparts. Similarly, up-market retailers promote scarcity and exclusivity and are unlikely to stock too many items that are the same. Comparisons can be made between products. The day of the week selected for the research to be conducted, Thursday was chosen.
- Modification in cut mark

- Qualification in the Emblessisment

- Mitigation of fabric consumption

- Adaptation of new trend

\section{Fashionable Designed Garments}

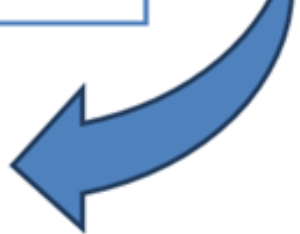




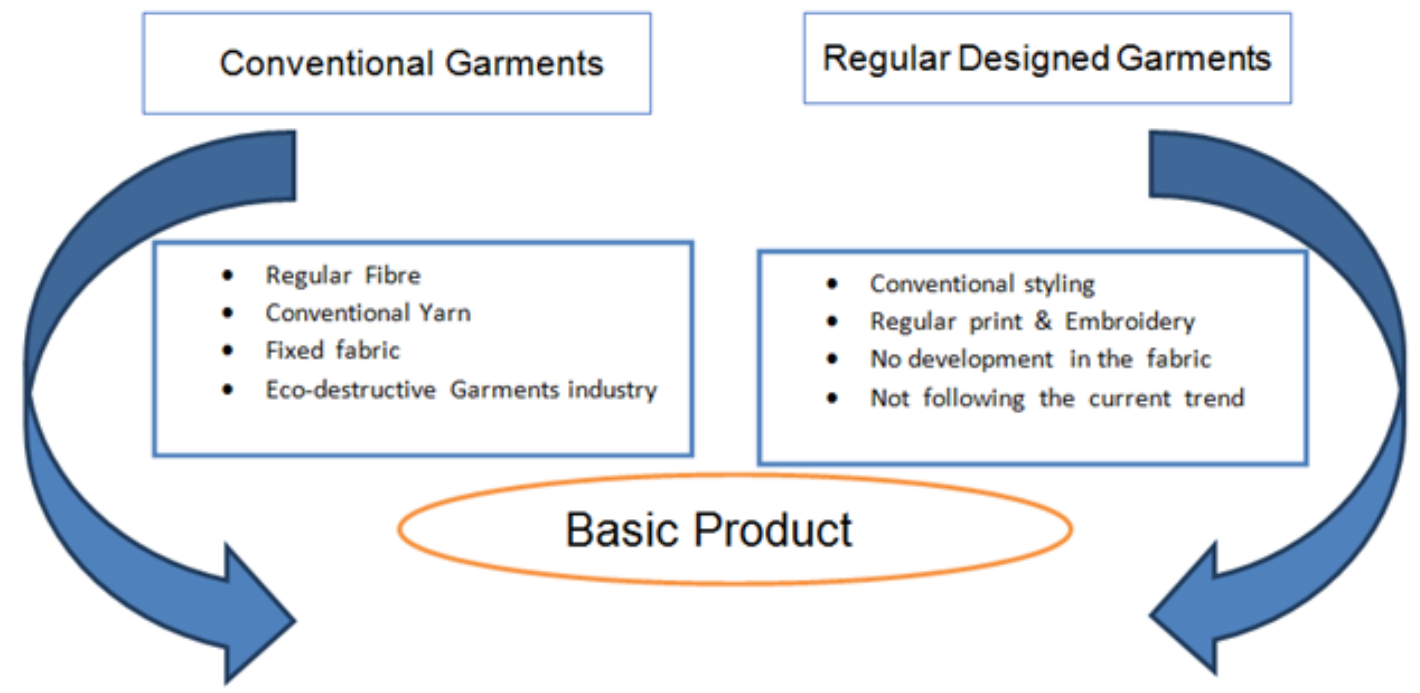

Figure 2 Formation of basic product.
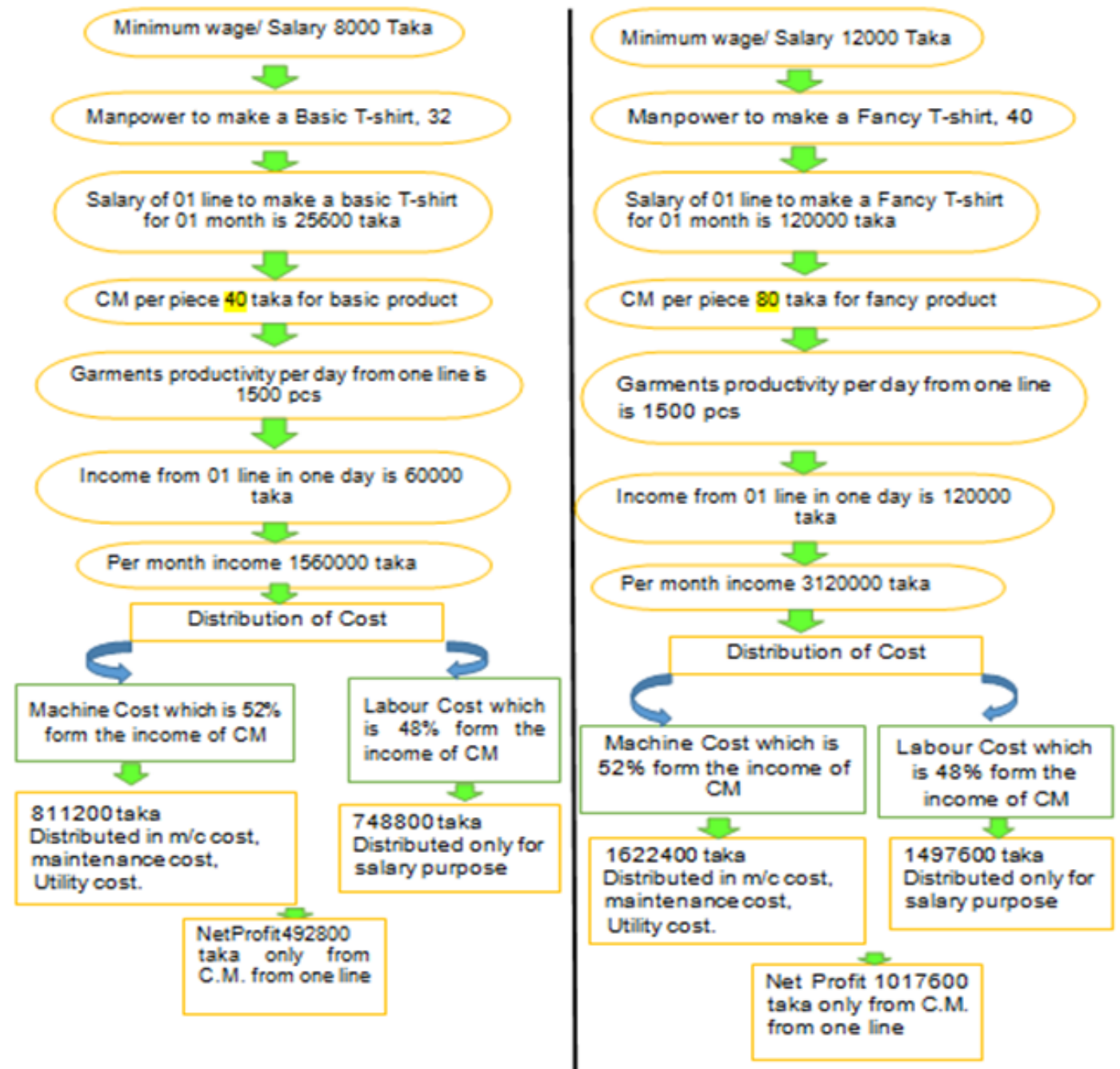

Figure 3 This figure represents the conceptual frame work minimum wage. To information has been demonstrated if the minimum wage is 800 taka than what is the profit. If the minimum wages is rise up to 1200 taka but we produce fancy product than what will be the net profit. 


\section{Result and discussion}

Different types of C.M. value from various factory of Bangladesh garments market:

The bar chart (Figure 4) depicts the information on the cost of manufacture of different products of different garments companies. It is seen from that chart that basic t-shirts C.M. range is almost $\$ 5 / \mathrm{dz}$ in the five kinds of company. In contrast with the basic T-shirt, fancy T-shirt's C.M. is almost $\$ 14-\$ 15$ which higher than basic. Similarly, the same pattern represents a basic long-sleeve T-shirt, tank top, polo shirts, trousers where the polo shirt's C.M. is higher than all of the products. Finally, it is found from the graph that the basic product's C.M is lower than fancy products in all types of factories (Table 1).

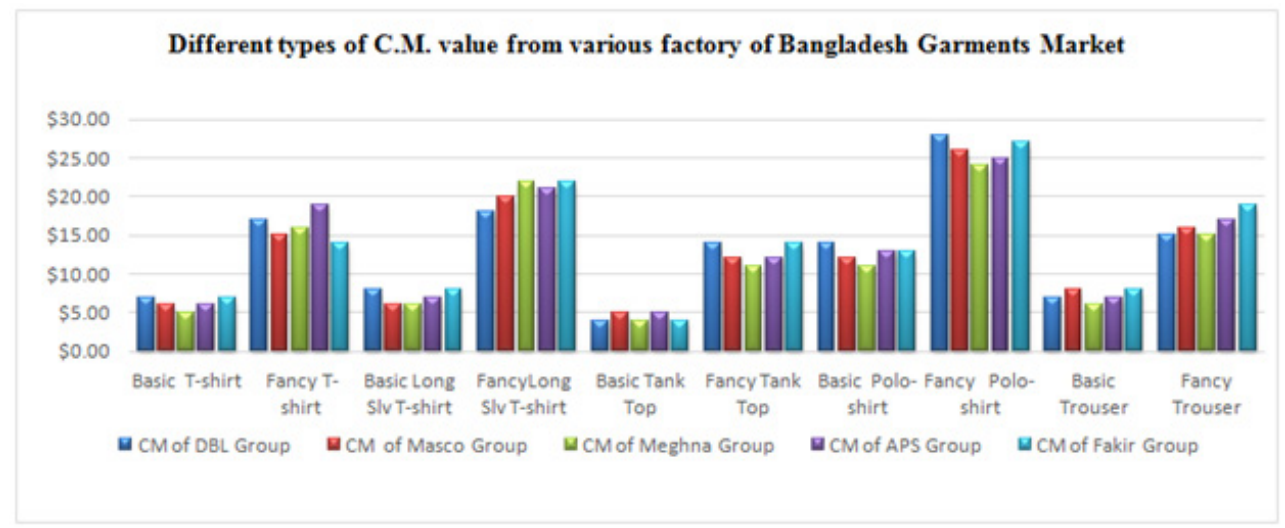

Figure 4 Variation of CM value in Bangladesh market.

Table I list of C.M value in Bangladesh market

\begin{tabular}{|c|c|c|c|c|c|c|c|c|c|c|}
\hline $\begin{array}{l}\text { Company } \\
\text { Name }\end{array}$ & $\begin{array}{l}\text { Basic } \\
\text { T-shirt }\end{array}$ & $\begin{array}{l}\text { Fancy } \\
\text { T-shirt }\end{array}$ & $\begin{array}{l}\text { Basic L. } \\
\text { Slv T-shirt }\end{array}$ & $\begin{array}{l}\text { Fancy L .Slv } \\
\text { T-shirt }\end{array}$ & $\begin{array}{l}\text { Basic } \\
\text { tank top }\end{array}$ & $\begin{array}{l}\text { Fancy } \\
\text { tank top }\end{array}$ & $\begin{array}{l}\text { Basic } \\
\text { polo-shirt }\end{array}$ & $\begin{array}{l}\text { Fancy } \\
\text { polo-shirt }\end{array}$ & $\begin{array}{l}\text { Basic } \\
\text { trouser }\end{array}$ & $\begin{array}{l}\text { Fancy } \\
\text { trouser }\end{array}$ \\
\hline $\begin{array}{l}\text { CM of DBL } \\
\text { Group }\end{array}$ & $\$ 7.00$ & $\$ 17.00$ & $\$ 8.00$ & $\$ 18.00$ & $\$ 4.00$ & $\$ 14.00$ & $\$ 14.00$ & $\$ 28.00$ & $\$ 7.00$ & $\$ 15.00$ \\
\hline $\begin{array}{l}\text { CM of Masco } \\
\text { Group }\end{array}$ & $\$ 6.00$ & $\$ 15.00$ & $\$ 6.00$ & $\$ 20.00$ & $\$ 5.00$ & $\$ 12.00$ & $\$ 12.00$ & $\$ 26.00$ & $\$ 8.00$ & $\$ 16.00$ \\
\hline $\begin{array}{l}\text { CM of Meghna } \\
\text { Group }\end{array}$ & $\$ 5.00$ & $\$ 16.00$ & $\$ 6.00$ & $\$ 22.00$ & $\$ 4.00$ & $\$ 11.00$ & $\$ 11.00$ & $\$ 24.00$ & $\$ 6.00$ & $\$ 15.00$ \\
\hline $\begin{array}{l}\text { CM of APS } \\
\text { Group }\end{array}$ & $\$ 6.00$ & $\$ 19.00$ & $\$ 7.00$ & $\$ 21.00$ & $\$ 5.00$ & $\$ 12.00$ & $\$ 13.00$ & $\$ 25.00$ & $\$ 7.00$ & $\$ 17.00$ \\
\hline $\begin{array}{l}\text { CM of Fakir } \\
\text { Group }\end{array}$ & $\$ 7.00$ & $\$ 14.00$ & $\$ 8.00$ & $\$ 22.00$ & $\$ 4.00$ & $\$ 14.00$ & $\$ 13.00$ & $\$ 27.00$ & $\$ 8.00$ & $\$ 19.00$ \\
\hline
\end{tabular}

\section{Comparison between the C.M. of different garments of different company}

The bar chart (Figure 5) provides the information about the difference of C.M. value between the fancy product \& basic in all categorical companies. It is seen that the green bar represents the difference between a basic T-shirt \& a fancy T-shirt. Here, the most remarkable thing is that the difference of the C.M. level (Table 2) is almost same in all factories. The rage for the T-shirt is. $\$ 5-\$ 6$. In this similarly pattern-difference label of C.M. for the rest of the items such as basic long-sleeve t-shirt, tank top, polo shirts, trousers are same. Finally, from the graph it is found that there is no significant difference in the C.M. value in the various types of garments manufacturer.

\section{Different types of overhead cost value from various factory of Bangladesh garments market}

The pie charts (Figure 6) depict the pattern of overhead cost for per machine of varies types of knit garments. It is seen that the overhead cost rate is different for different types of factories, the range is not too inconsistence. They are different because of the setup of the factory.
Moreover, monthly expenditure is another reason for this difference. Here in Table 3 we can see the highest overhanded cost is $\$ 45$ which contains in the yellow portion against the company fakir fashion. And the lowest overhead cost is $\$ 32$ for the Meghna group. Finally, the pie chart shows the overhead cost range for the Bangladesh garments market which is directly hit by the worker's salary range.

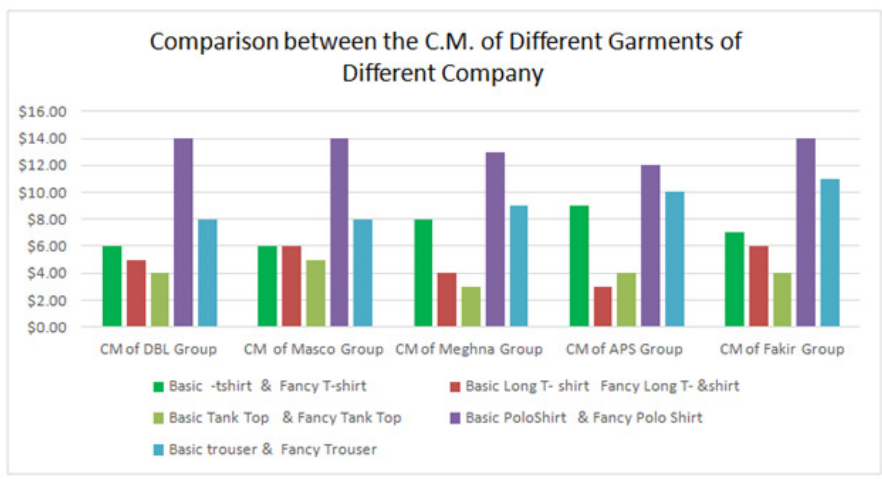

Figure 5 Comparison of CM value in Bangladesh market. 


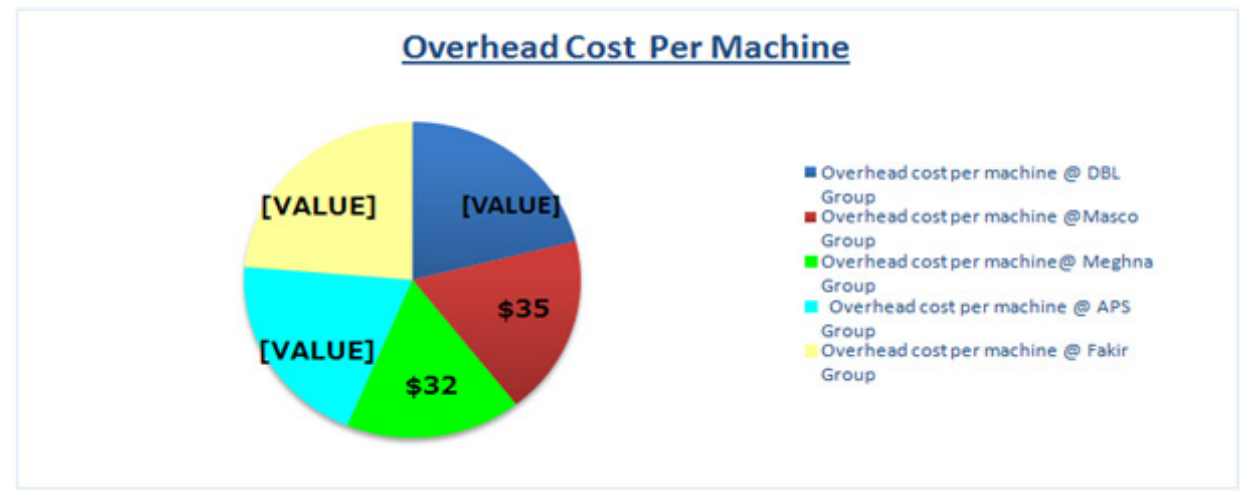

Figure 6 Overhead value of different garments.

Table 2 Comparison of C.M value in Bangladesh market

\begin{tabular}{llllll}
\hline Company & $\begin{array}{l}\text { Basic -t-shirt } \\
\text { \& Fancy } \\
\text { T-shirt }\end{array}$ & $\begin{array}{l}\text { Basic Slv T- shirt } \\
\text { Fancy L.SlvT- } \\
\text { \&shirt }\end{array}$ & $\begin{array}{l}\text { Basic tank top } \\
\text { \& fancy tank } \\
\text { top }\end{array}$ & $\begin{array}{l}\text { Basic polo shirt } \\
\text { \& fancy polo } \\
\text { shirt }\end{array}$ & $\begin{array}{l}\text { Basic trouser \& } \\
\text { fancy trouser }\end{array}$ \\
\hline CM of DBL Group & $\$ 6.00$ & $\$ 5.00$ & $\$ 4.00$ & $\$ 14.00$ & $\$ 8.00$ \\
CM of Masco Group & $\$ 6.00$ & $\$ 6.00$ & $\$ 5.00$ & $\$ 14.00$ & $\$ 8.00$ \\
CM of Meghna Group & $\$ 8.00$ & $\$ 4.00$ & $\$ 3.00$ & $\$ 13.00$ & $\$ 9.00$ \\
CM of APS Group & $\$ 9.00$ & $\$ 3.00$ & $\$ 4.00$ & $\$ 12.00$ & $\$ 10.00$ \\
CM of Fakir Group & $\$ 7.00$ & $\$ 6.00$ & $\$ 4.00$ & $\$ 14.00$ & $\$ 11.00$ \\
\hline
\end{tabular}

Table 3 Overhead cost per machine

\begin{tabular}{lllll}
\hline DBL group & Masco group & Meghna group & APS group & Fakir group \\
\hline$\$ 40$ & $\$ 35$ & $\$ 32$ & $\$ 38$ & $\$ 45$ \\
\hline
\end{tabular}

\section{Garments costing summary, C.M percentage \& back to back percentage}

In the above (Table 4) we can see a cost summary for a basic T-shirt. The pie chart (Figure 7) represents the CM percentage \& back-to-back percentage. The majority of the potions are blue, which represents the back-to-back percentage of the cost of garments. On the other hand, the red portion is the C.M. portion which covers the $35 \%$ of the total cost. In the garments industry, the worker's salary has been considered from C.M. portion.

Table 4 Garments costing and back to back percentage

\begin{tabular}{ll}
\hline Total garments costing & \multicolumn{1}{c}{ Image } \\
\hline Fabric consumption & $3 \mathrm{~kg}$ \\
Fabric Price & $\$ 6.00$ \\
Total & $\$ 15.00$ \\
Trims & $\$ 3.00$ \\
Print & $\$ 4.00$ \\
CM & $\$ 7.00$ \\
Others + Commercial cost $(3 \%)$ & $\$ 0.87$ \\
Total Price /dz & $\$ 29.87$ \\
Total Price /pc & $\$ 2.49$ \\
\hline
\end{tabular}

\begin{tabular}{ll}
\hline Back to Back Percentage & $64.43 \%$ \\
Cm Percentage & $35.57 \%$
\end{tabular}

\section{Garments costing and Back to back percentage}

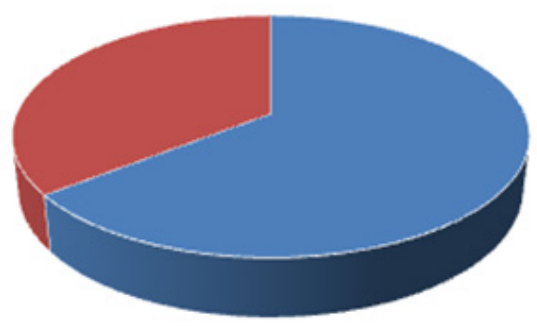

\section{- Back to Back Perchantage $\quad$ Cm Percentage}

Figure 7 Ratio of CM percentage and back to back percentage.

\section{Example of overhead cost of a factory}

In order to do the calculation of CM cost for any kind of major area overhead cost must be necessary. From the survey we have summaries of the overhead cost in the garments industry (Table 5).

In the table number 5 we have shown how to calculate the overhead cost per machine. The most important thing is that the 
maximum factory fixed their overhead cost as per their expense as well as the target of profit percentage. On the other hand, overhead cost per machine is used to find out the CPM of a garments factory. This is fixed for the minimum factory. minute

$\mathrm{CPM}=($ overhead cost per machine $/ 600)=\$ 37 / 600=0.06 /$ per

$$
\text { C.M. }=\text { CPM x SMV of a Garments }=.06 \times 6=\$ 3.60 / \mathrm{dz}
$$

Table 5 Over head cost

\begin{tabular}{ll} 
Total Monthly Expense & $40,000,000$ taka \\
Working day & 26 days \\
Per day Expense & $1,538,462$ taka \\
No of sewing machine & 500 pcs \\
Overhead cost per machine & 3,077 taka \\
Overhead cost per machine & $\$ 37.52$ \\
\hline
\end{tabular}

\section{Break down of monthly expense of a garment}

The bar chart (Figure 8) expresses the most important data of this research. Where we can see, from Table 6 that out of the total 4 million taka and 2 million taka. Which is the expensing in every month. This is $50 \%$ of the total expense of the month. The orange color bar represents the salary data. The salary data is not so closer against the salary bar. In order to solve this research problem, we have to give more attention to this area. Finally, from the graph it is found that the salary is the most vital expense to run a factory. Besides, if the salary structure is perfect, then the company will run swiftly.

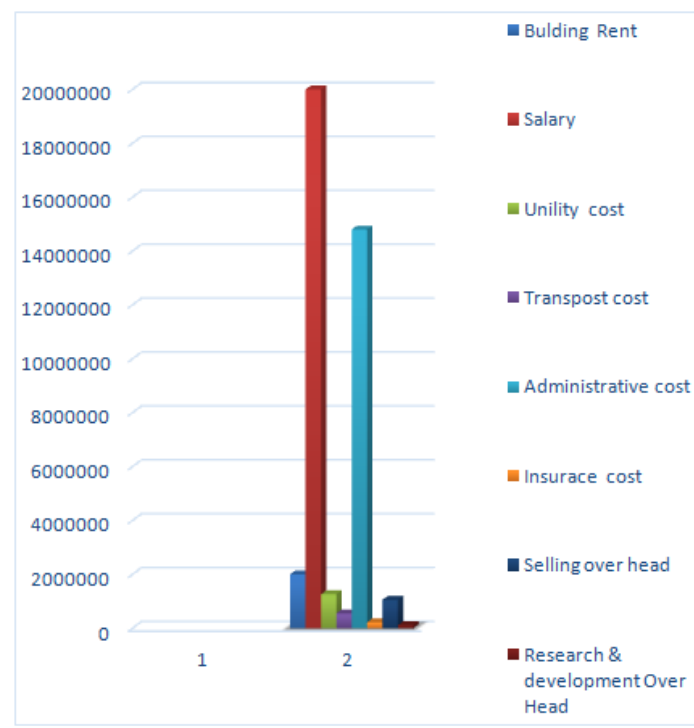

Figure 8 break down of monthly expense of a company.

Table 7 Comparison between Basic products with fancy product
Table 6 Break Down of Total monthly Expense (taka)

\begin{tabular}{ll}
\hline Building Rent & 2000000 \\
Salary & 20000000 \\
Utility cost & 1260000 \\
Transport cost & 550000 \\
Administrative cost & 14800000 \\
Insurance cost & 219000 \\
Selling over head & 1055000 \\
Research \& development Over Head & 116000 \\
\hline Total & 4000000
\end{tabular}

How fancy product is more strategic than basic product:

The above chart (Figure 9) represents the whole summary of this research. The diagram provides the transformation of a fancy product. If any company wants to earn $\$ 30$ lac with including salary \& profit up they have to produce 30000 pcs product in a month. If the average cost of making of those garments is $\$ 5$ than its required 60 days to reach the target. This is not compatible. By the basic product it's not possible to meet the target. If the average cost of making those garments is $\$ 12$, then it is required only 25 days to reach the target. This is more adequate for a month. For this kind of achievement a fancy product is the main weapon to reach this goal (Table 7).

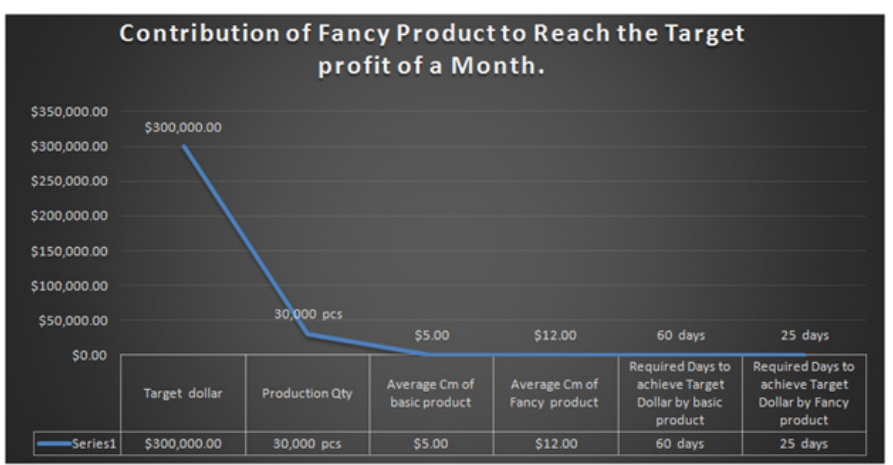

Figure 9 Strategic presentation to catch the target profit by using basic product and fancy product.

\section{Conclusion}

To sum up, as per the research topic, the minimum wage is human rights, so it cannot be thrown down from the business sector. On the other hand, our Bangladesh market is growing up based on the cheap labor cost. Due to cheap labor cost, we can meet the target price from the buyer. Yes, the minimum wage will increase from year to year. As a consequence, we have to make fashion-based garments market to deal with price. In additionally, sustainability is other linking concepts which can accelerate the selling of fancy products in the Europe market. However, the authors are very happy to carry out this research and hope this will be beneficial in everyone's professional life.

\begin{tabular}{llllll}
\hline $\begin{array}{l}\text { A } \\
\text { month }\end{array}$ & $\begin{array}{l}\text { Target } \\
\text { dollar }\end{array}$ & $\begin{array}{l}\text { Production } \\
\text { Qty }\end{array}$ & $\begin{array}{l}\text { Average } \\
\text { Cm of basic } \\
\text { product }\end{array}$ & $\begin{array}{l}\text { Average Cm of } \\
\text { Fancy product }\end{array}$ & $\begin{array}{l}\text { Required days to achieve } \\
\text { target dollar by basic product }\end{array}$ \\
\hline A month & $\$ 300,000.00$ & 30,000 pcs & $\$ 5.00$ & $\$ 12.00$ & 60 days \\
\hline
\end{tabular}

\section{Acknowledgments}

The author would like to offer cordial gratitude to Mr. Engr.
Eanamul Haque Nizam for his everlasting encouragement and support of this research. 


\section{Funding}

None.

\section{Conflicts of interest}

No potential conflict of interest was reported by the authors.

\section{References}

1. Big business ahead for garments sector. The Daily Star. 2019.

2. Bangladesh competing well against Vietnam in US textile and apparel market. 2019

3. Sheng Lu. Minimum wage in the apparel industry continues to rise in most Asian Countries in 2016. FASH455 Global Apparel \& Textile Trade and Sourcing; 2017:1-14

4. Fashion merchandising: garment costing. 2019.

5. Analysis of consumer buying behaviour in garments. 2019.
6. Apparel and clothing market Europe - Statistics \&amp; Facts. Statista; 2019.

7. Can Fast Fashion Be Sustainable? What Is Fast Fashion?

8. Future prospects of RMG sector of Bangladesh. - Textile engineering students - solution for textile studies. 2019.

9. Bhardwaj V, Fairhurst A. Fast fashion: response to changes in the fashion in-dustry. The International Review of Retail, Distribution and Consumer Research. 2010;20(1):165-173.

10. Bhardwaj V, Fairhurst A. Fast fashion: response to changes in the fashion in-dustry. The International Review of Retail, Distribution and Consumer Research. 2010;20(1):165-173.

11. Cady S, Jacobs R, Koller R, et al. The Change Formula: Myth, legend, or lore? OD Practitioner. 2014;46(3):32-39.

12. Carbonaro S, Votava C. The function of fashion? The design of new styles of thought. The Nordic Textile Journal. 2009:30-45. 